Barker, P.F., Camerlenghi, A., Acton, G.D., and Ramsay, A.T.S. (Eds.)

Proceedings of the Ocean Drilling Program, Scientific Results Volume 178

\title{
2. Data Report: Dinoflagellate CySt ANALYSIS OF NEOGENE SEDIMENTS FROM SITES 1095 AND 1096, Antarctic Peninsula Continental Rise'
}

\author{
Carol J. Pudsey² and Rex Harland ${ }^{3}$
}

\begin{abstract}
Protoperidiniacean dinoflagellate cysts were identified in 19 of 28 samples from two sites on the Antarctic Peninsula continental rise. Cysts are most common in the lower Pliocene and upper Miocene and include species of Brigantedinium, Lejeunecysta, and Selenopemphix. Autotrophic gonyaulacacean dinoflagellate cysts are very rare in the samples. The dominance of taxa derived from assumed heterotrophic dinoflagellate motile forms may indicate high nutrient content in the surface waters, which sustained a considerable diatom population.
\end{abstract}

\section{INTRODUCTION}

The occurrence of dinoflagellate cysts in Neogene and Holocene sediments from the Southern Ocean is now becoming reasonably well documented. For some years it was thought that there were no postPaleogene dinoflagellate cysts within Southern Ocean sediments (McMinn, 1995) because the geographical and thermal isolation of Antarctica had effectively prevented the migration of the dinoflagellates that produce hypnozygotic cysts. Recent research (Marret and de Vernal, 1997; Harland et al., 1998, 1999; Harland and Pudsey, 1999), however, has established the occurrence of dinoflagellate cysts, which were found in sediment traps and Quaternary sediments, within the waters of the Southern Ocean. In addition, Wrenn et al. have reported di-
'Pudsey, C.J., and Harland, R., 2001. Data report: Dinoflagellate cyst analysis of Neogene sediments from Sites 1095 and 1096, Antarctic Peninsula continental rise. In Barker, P.F., Camerlenghi, A., Acton, G.D., and Ramsay, A.T.S. (Eds.), Proc. ODP, Sci. Results, 178, 1-10 [Online]. Available from World Wide Web: $<$ http://www-odp.tamu.edu/ publications/178_SR/VOLUME/ CHAPTERS/SR178_02.PDF>. [Cited YYYY-MM-DD]

${ }^{2}$ British Antarctic Survey, High Cross, Madingley Road, Cambridge CB3 OET, United Kingdom. cjp@pcmail.nerc-bas.ac.uk ${ }^{3}$ DinoData Services, 50, Long Acre, Bingham, Nottingham NG13 8AH United Kingdom.

Initial receipt: 14 August 2000 Acceptance: 5 February 2001

Web publication: 7 June 2001 Ms 178SR-208 
noflagellate cysts from the lower Miocene and Quaternary of East Antarctica by Wrenn et al. (1999). Our contribution aims to add to the knowledge of Southern Ocean Neogene dinoflagellate cysts by describing assemblages from the Miocene and Pliocene of the Antarctic Peninsula margin, recovered during Ocean Drilling Program (ODP) Leg 178, Sites 1095 and 1096.

\section{MATERIALS AND METHODS}

Twenty-eight samples were selected for dinoflagellate cyst analysis. The samples were taken from the Neogene and Quaternary of Holes 1095B, 1096B, and 1096C on the continental rise west of the Antarctic Peninsula (Fig. F1). Lithologies are mainly diatom-bearing silty clays and diatom silty clays, with muddy diatom oozes in the lower Pliocene and barren claystone at the base of Hole 1095B (Table T1) (Barker, Camerlenghi, Acton et al., 1999). Biogenic silica (in the form of diatoms, radiolarians, and rare silicoflagellates) was measured by point counting a smear slide made from each sample. The more expanded sequence at Site 1096 was sampled down to 513 meters below seafloor (mbsf) ( 4.2 $\mathrm{Ma})$, and Site 1095 was sampled from $122 \mathrm{mbsf}(\sim 4.2 \mathrm{Ma})$ to the base of the hole, which dates $\sim 10 \mathrm{Ma}$. Lithologic cyclicity is evident in many of the sedimentary sequences, with fine-grained laminated sediments alternating with bioturbated, sandier lithologies on a scale of decimeters to meters. Several pairs of dinoflagellate samples were taken from these alternating lithologies. Sample depths were converted to age using the paleomagnetic timescale provided in Barker, Camerlenghi, Acton et al. (1999; tables T38, T34), with linear interpolation between magnetic reversal datum points.

All the samples were prepared using the standard palynological preparation technique as outlined by Wood et al. (1996), except for the use of oxidizing reagents, which were avoided to prevent the loss of the protoperidiniacean dinoflagellate cysts (Dale, 1976). The samples were treated qualitatively, as the numbers of cysts recovered were low, and indeed, some of the samples proved to be entirely barren of cysts. The sample residues were stained with Safranin, made up onto strewn slides, and examined at 10x using a Zeiss Axiolab microscope.

\section{RESULTS}

Dinoflagellate cysts were recovered in 19 of the 28 samples, though some of the assemblages are very poorly preserved. Structured organic matter (STOM) or unstructured organic matter (USTOM) is present in almost all samples, and foraminiferal linings occur in most samples older than $6 \mathrm{Ma}$ (Table T1). A few specimens of angiosperm pollen grains and spores were noted within the sample suite. The occurrence of the dinoflagellate cyst taxa is plotted against age in Figures F2 and F3, with the raw-count data given in Table T2.

Samples 178-1096B-3H-1, 140-142 cm, 3H-4, 140-142 cm, 20H-4, $39-41 \mathrm{~cm}$, and $20 \mathrm{H}-6,39-41 \mathrm{~cm}(14.7,19.2,162.6$ and $165.6 \mathrm{mbsf}$, RH313 to RH316 [laboratory-assigned numbers]), and samples 1781095B-5H-1, 108-110 cm (122.1 mbsf, RH302),-5H-4, 94-96 cm (126.4 mbsf, RH303), and 26X-7, 4-6 cm (211.9 mbsf, RH403), which dated as Pleistocene isotope Stage 7 to early Pliocene in age, proved to be virtually barren of palynomorphs but do contain USTOM and STOM to-
F1. Location map of Sites 1095 and 1096, p. 6.

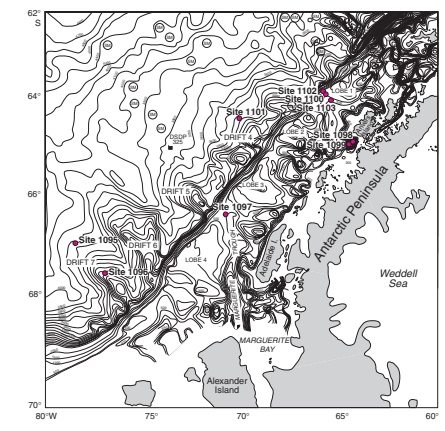

T1. Lithology and range of recovered palynomorphs, p. 9.

F2. Cumulative bar chart of the occurrence of dinoflagellate cysts, p. 7.

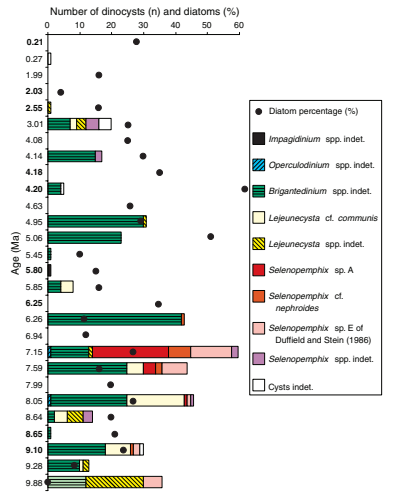

F3. Plots of the abundance of each cyst taxon, p. 8.

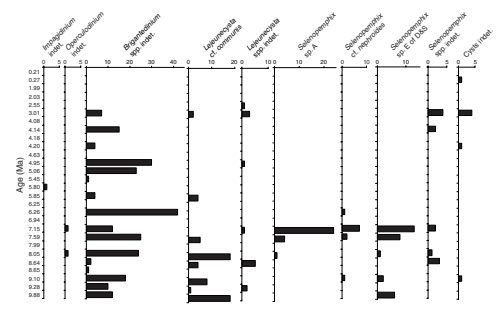

T2. Occurrence of dinoflagellate cyst taxa, p. 10. 
gether with the occasional angiosperm pollen grain and bisaccate. In contrast, Samples 178-1096C-12X-3, 141-143 cm, 33X-2, 120-122 cm, and $34 \mathrm{X}-1,115-117 \mathrm{~cm}(302.3,503.7$, and $512.55 \mathrm{mbsf}$; RH317 to RH319), which are late to early Pliocene in age, contain assemblages of dinoflagellate cysts mostly assignable to the genera Brigantedinium, Lejeunecysta and Selenopemphix. All these fossil cyst genera have been associated with the modern genus Protoperidinium and are therefore assumed to have a heterotrophic nutritional strategy. Their occurrence within these samples indicates the presence of water with a high nutrient content.

Samples 178-1095B-9H-3, 100-102 cm, and 9H-6, 91-93 cm (163.0 and 167.4 mbsf, RH304 and RH305), dated as early Pliocene in age, contained some dinoflagellate cysts that were identified to the genus Brigantedinium. These assemblages also contained rare angiosperm pollen grains and foraminiferal linings. Unfortunately, the palynomorph assemblages do not offer any biostratigraphic information on the age of the samples. Some angiosperm pollen was observed in Sample 1781095B-12H-1, 81-83 cm (188.3 mbsf, RH395), together with the first foraminiferal linings downcore and some evidence of reworking from Upper Cretaceous sediments. A single specimen of Brigantedinium sp. indet. was also recovered from this sample.

Samples 178-1095B-14X-1, 19-21 cm, and 14X-2, 135-137 cm (205.2 and 207.8 mbsf; RH306 and RH307), which dated as late Miocene, are almost devoid of palynomorphs, but contain USTOM, STOM, the occasional spore, and angiosperm pollen together with limited numbers of dinoflagellate cysts. The cysts present mostly occur in 178-1095B-14X-2, 135-137 cm, and consist of Brigantedinium spp. indet. and Lejeunecysta cf. communis Biffi and Grignani, 1983.

Sample 178-1095B-17X-4, 17-19 cm (238.6 mbsf, RH397), yielded a reasonable dinoflagellate cyst assemblage consisting almost entirely of Brigantedinium spp. indet. and Selenopemphix cf. nephroides Benedek, 1972, together with foraminiferal linings, pollen, and spores. The samples above and below, 178-1095B-17X-2, 119-121 cm, and 23X-1, 100$102 \mathrm{~cm}$ (236.7 and 292.7 mbsf, RH396 and RH398), lack dinoflagellate cysts although some pollen and spores were observed.

The remaining upper Miocene samples, except for 178-1095B-29X-1, $126-128 \mathrm{~cm}$, and $34 \mathrm{X}-6,34-35 \mathrm{~cm}$ (350.8 and $405.1 \mathrm{mbsf}$, RH309 and RH401), which were almost barren, contained reasonable dinoflagellate cyst assemblages, including species of Lejeunecysta and Selenopemphix that have been associated with Miocene sediments. The assemblages consist entirely of cyst taxa attributable to the Protoperidiniaceae and are therefore thought to be heterotrophic in their nutritional strategy. Dinoflagellate cysts attributable to the Gonyaulacaceae are notably ab-

sent. Foraminiferal linings, pollen, and spores are also present. The dominance of taxa derived from assumed heterotrophic dinoflagellate motile forms may again indicate the presence of water with high nutrient content sustaining a considerable diatom population (but see later discussion).

\section{DISCUSSION}

The dinoflagellate cysts in these samples appear to be autochthonous, with minimal evidence of reworking from older material. The cysts were recovered mostly within the Miocene part of the sequence and were dominated by congruentidiacean, now protoperidiniacean, 
cysts. These are not well known in the published dinoflagellate literature; it is suspected that some may be new to science, and they are being studied further to provide detailed taxonomic descriptions. Virtually all the dinoflagellate cysts recovered can be assigned to or associated with the modern heterotrophic dinoflagellate Protoperidinium. By comparison with our knowledge of the modern cyst flora, which also is dominated by Protoperidinium cysts (Harland et al., 1998), a similar cold-water setting with high nutrient content can be interpreted for the sampled horizons. It is most probable that these dinoflagellates were feeding upon diatom populations that were taking advantage of seasonality and high supply of nutrients. The lack of autotrophic gonyaulacacean dinoflagellate cysts is noteworthy.

Similar situations, especially within the Miocene, have also been recognized elsewhere in the world, for example, at high latitudes in both the Labrador Sea and Baffin Bay (Head et al., 1989a, 1989b, 1989c), in the Gulf of Mexico (Duffield and Stein, 1986), and from the eastern seaboard of the United States (de Verteuil and Norris, 1992).

The relationship between diatom content and dinoflagellate cyst content of the samples, however, is not straightforward (Fig. F2). Many diatomaceous samples contain few or no dinoflagellate cysts. Diatoms were most abundant from 4 to 5.3 Ma (see Pudsey, Chap. 25, this volume), whereas dinoflagellate cysts attained highest abundance and diversity between 7 and $8 \mathrm{Ma}$. Dinoflagellate cysts persist at the base of the section where diatoms become less common because of silica dissolution. In the pairs of samples from bioturbated and laminated facies, the bioturbated sample tends to be the poorer in dinoflagellate cysts (e.g., samples at 4.20 Ma compared with 4.14 Ma, 5.80/5.85 Ma, 6.25/ 6.26 Ma, and 8.65/8.64 Ma). Foraminiferal linings are also less common in the bioturbated samples so this may simply be a preservational bias.

Finally, all the samples are almost barren of terrestrial palynomorphs such as angiosperm pollen, bisaccate grains, and spores, and only two of the samples contained any reworked material.

\section{ACKNOWLEDGMENTS}

The samples, provided by ODP, were collected aboard ship during Leg 178, and we thank all the members of the sample shifts. This research was supported by the Natural Environment Research Council, U.K. The Centre for Palynology at the University of Sheffield and Mr. S. Ellin are thanked for providing facilities and for supervision of sample processing. We thank Dr. P.F. Barker for encouragement to go ahead with this work and one anonymous referee for helpful comments on the paper. 


\section{REFERENCES}

Barker, P.F., Camerlenghi, A., Acton, G.D., et al., 1999. Proc. ODP, Init. Repts., 178 [CDROM]. Available from: Ocean Drilling Program, Texas A\&M University, College Station, TX 77845-9547, USA.

Dale, B., 1976. Cyst formation, sedimentation, and preservation: factors affecting dinoflagellate assemblages in Recent sediments from Trondheimsfjord, Norway. Rev. Palaeobot. Palynol., 22:39-60.

de Verteuil, L., and Norris, G., 1992. Miocene Protoperidiniacean dinoflagellate cysts from the Maryland and Virginia coastal plain. In Head, M.J., and Wrenn, J.H. (Eds.), Neogene and Quaternary Dinoflagellate Cysts and Acritarchs. Am. Assoc. Stratigr. Palynol. Found., 391-430.

Duffield, S.L., and Stein, J.A., 1986. Peridiniacean-dominated dinoflagellate cyst assemblages from the Miocene of the Gulf of Mexico, off-shore Louisiana. In Wrenn, J.H., Duffield, S.L., and Stein, J.A. (Eds.), Papers From the First Symposium on Neogene Dinoflagellate Cyst Biostratigraphy. Am. Assoc. Stratigr. Palynol. Contrib. Ser., 17:27-45.

Harland, R., FitzPatrick, M.E.J., and Pudsey, C.J., 1999. Latest Quaternary dinoflagellate cyst climatostratigraphy for three cores from the Falkland Trough, Scotia and Weddell seas, Southern Ocean. Rev. Palaeobot. Palynol., 107:265-281.

Harland, R., and Pudsey, C.J., 1999. Dinoflagellate cysts from sediment traps deployed in the Bellingshausen, Weddell and Scotia seas, Antarctica. Mar. Micropaleontol., 37:77-99.

Harland, R., Pudsey, C.J., Howe, J.A., and FitzPatrick, M.E.J., 1998. Recent dinoflagellate cysts in a transect from the Falkland Trough to the Weddell Sea, Antarctica. Palaeontology, 41:1093-1131.

Head, M.J., Norris, G., and Mudie, P.J., 1989a. New species of dinocysts and a new species of acritarch from the upper Miocene and lowermost Pliocene, ODP Leg 105, Site 646, Labrador Sea. In Srivastava, S.P., Arthur, M.A., Clement, B., et al., Proc. ODP, Sci. Results, 105: College Station, TX (Ocean Drilling Program), 453-466.

- 1989b. Palynology and dinocyst stratigraphy of the Miocene in ODP Leg 105, Hole 645E, Baffin Bay. In Srivastava, S.P., Arthur, M.A., Clement, B., et al., Proc. ODP, Sci. Results, 105: College Station, TX (Ocean Drilling Program), 467-514.

- 1989c. Palynology and dinocyst stratigraphy of the upper Miocene and lowermost Pliocene, ODP Leg 105, Site 646, Labrador Sea. In Srivastava, S.P., Arthur, M.A., Clement, B., et al., Proc. ODP, Sci. Results, 105: College Station, TX (Ocean Drilling Program), 423-451.

Marret, F., and de Vernal, A., 1997. Dinoflagellate cyst distribution in surface sediments of the southern Indian Ocean. Mar. Micropaleontol., 29:367-392.

McMinn, A., 1995. Why are there no post-Paleogene dinoflagellate cysts in the Southern Ocean? Micropaleontology, 41:383-386

Wood, G.D., Gabriel, A.M., and Lawson, J.C., 1996. Palynological techniques: processing and microscopy. In Jansonius, J., and McGregor, D.C. (Eds.), Palynology: Principles and Applications (Vol. 1). Am. Assoc. Stratigr. Palynol. Found., 29-50.

Wrenn, J.H., Hannah, M.J., and Raine, I.J., 1999. Paleoenvironmental significance and species diversity of early Miocene and Quaternary marine palynomorphs from the Cape Roberts no. 1 core, Ross Sea, Antarctica. Palynology, 23:268-269. 


\section{C.J. Pudsey and R. Harland}

Data Report: Dinoflagellate Cyst Analysis of Neogene Sediments

Figure F1. Location map of Sites 1095 and 1096. Bathymetry is in meters.

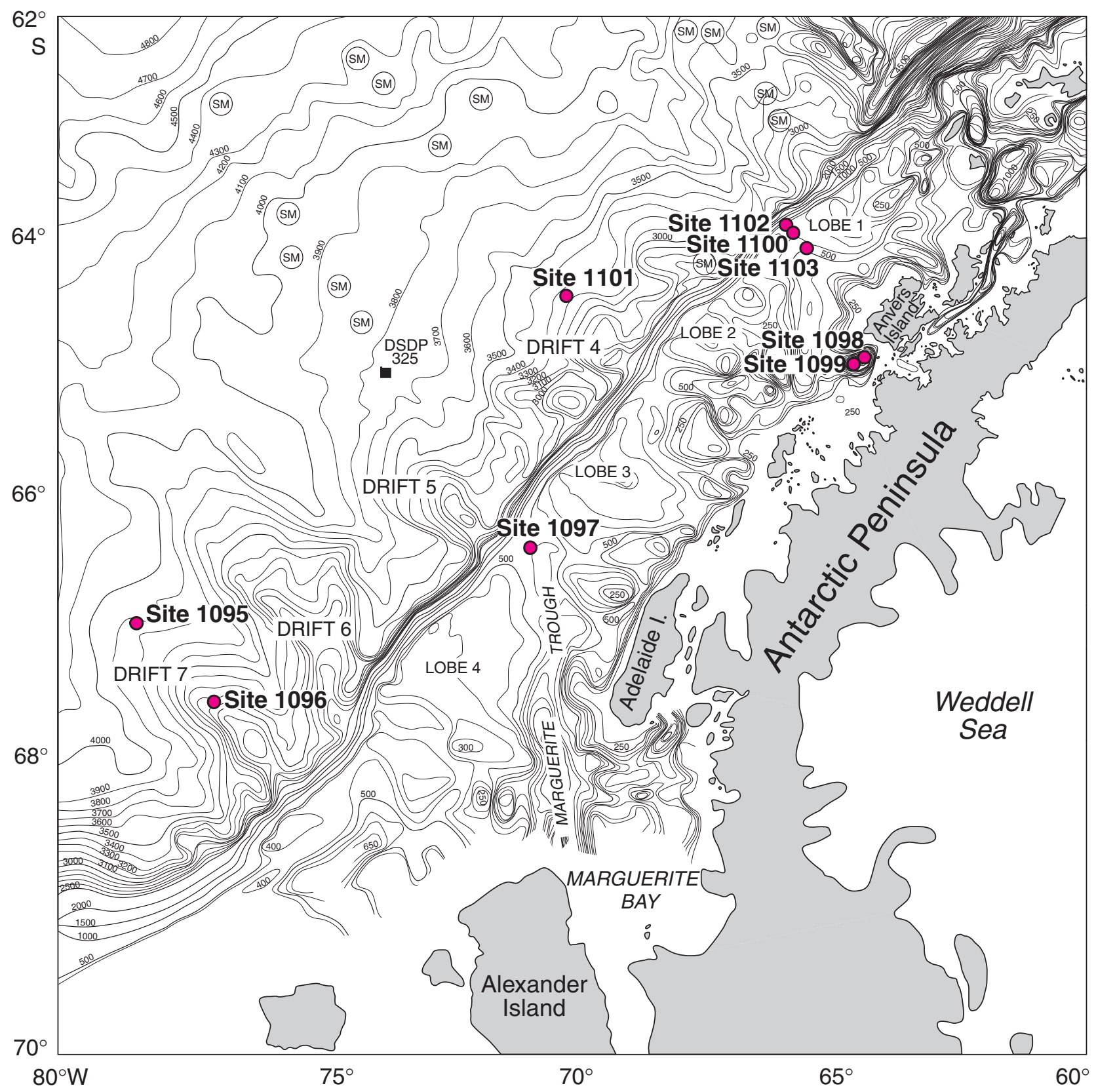




\section{C.J. Pudsey and R. harland}

Figure F2. Cumulative bar chart of the occurrence of dinoflagellate cysts, plotted against age. Diatom percentage is also shown by black circles on the same scale. Samples from bioturbated intervals are shown in bold type on the age scale; samples from laminated intervals are in light type.

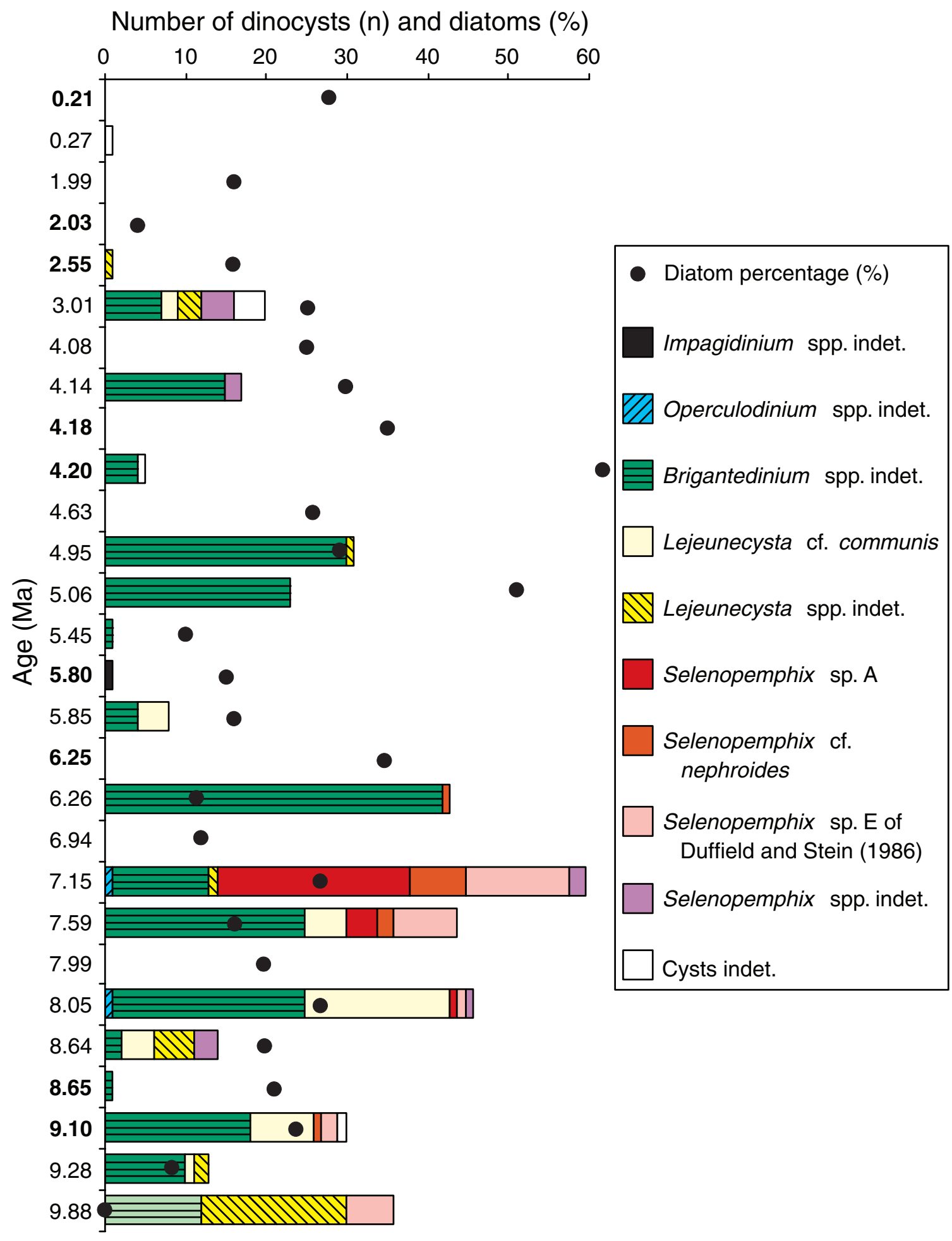


Figure F3. Plots of the abundance of each cyst taxon (numbers of cysts) against age. D\&S = Duffield and Stein (1986).

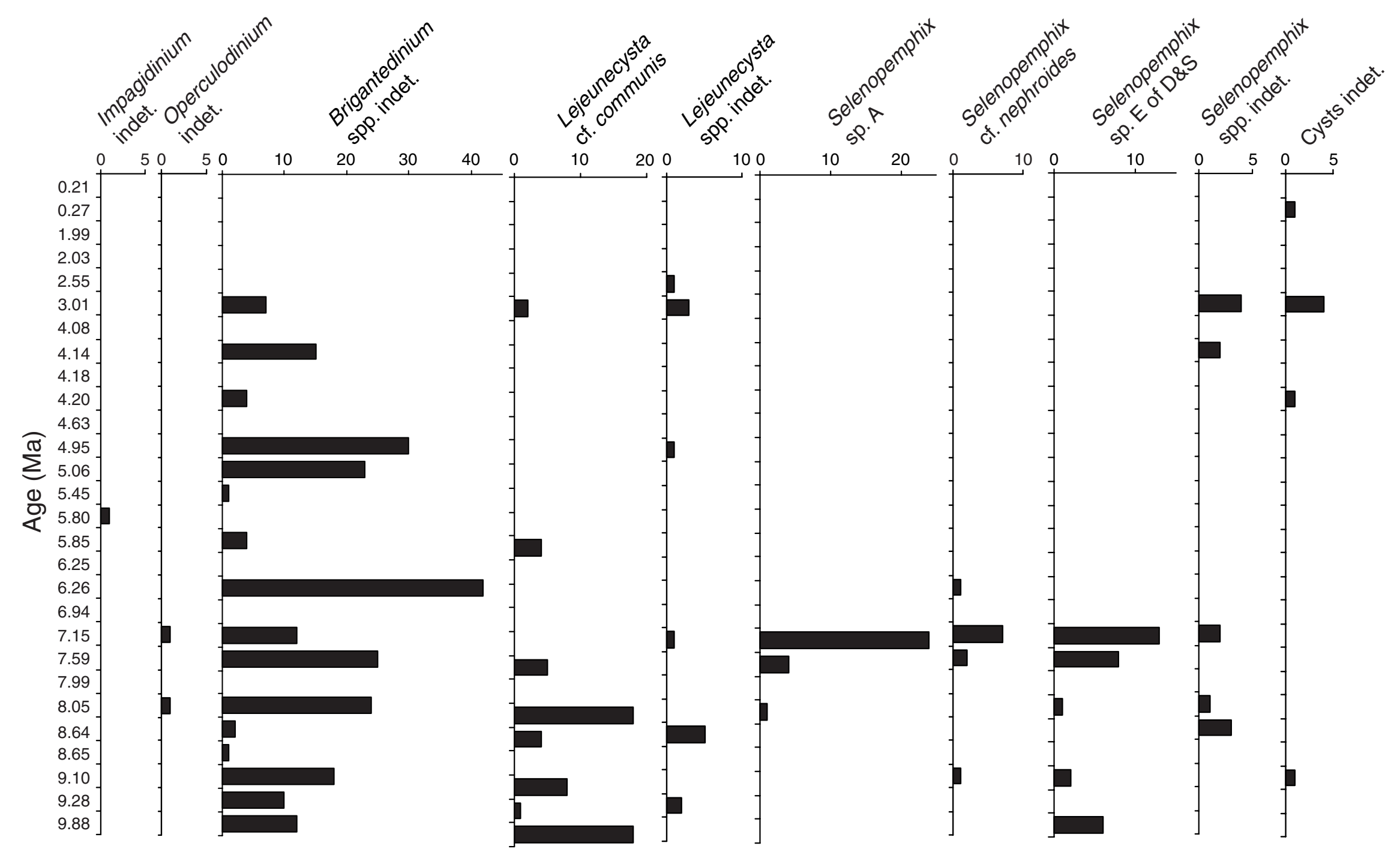


C.J. Pudsey and R. Harland

Data Report: Dinoflagellate Cyst Analysis of Neogene Sediments

Table T1. Sample list of lithology and the range of recovered palynomorphs.

\begin{tabular}{|c|c|c|c|c|c|c|c|c|c|c|}
\hline Sample & $\begin{array}{l}\text { Core, section, } \\
\text { interval }(\mathrm{cm})\end{array}$ & $\begin{array}{l}\text { Depth } \\
\text { (mbsf) }\end{array}$ & $\begin{array}{l}\text { Age } \\
(\mathrm{Ma})\end{array}$ & STOM & USTOM & Pollen & Spores & $\begin{array}{l}\text { Foraminifer } \\
\text { linings }\end{array}$ & Dinocysts & Lithology \\
\hline RH313 & 1096B-3H-1, 140-142 & 14.70 & 0.21 & $x$ & $x$ & & & & & Diatom silty clay, B \\
\hline $\mathrm{RH} 314$ & 1096B-3H-4, 140-142 & 19.20 & 0.27 & $x$ & $x$ & $x$ & & & $x$ & Silty clay \\
\hline RH315 & 1096B-20H-4, 39-41 & 162.59 & 1.99 & $x$ & $x$ & & & & & Diatom-bearing silty clay \\
\hline RH316 & 1096B-20H-6, 39-41 & 165.59 & 2.03 & & $x$ & & & & & Silty clay, B \\
\hline RH403 & 1096B-26X-7, 4-6 & 211.94 & 2.55 & $x$ & $x$ & $x$ & $x$ & & $x$ & Diatom-bearing silty clay, B \\
\hline RH317 & 1096C-12X-3, 141-143 & 302.34 & 3.01 & & $x$ & & & & $x$ & Diatom silty clay \\
\hline RH302 & 1095B-5H-1, 108-110 & 122.08 & 4.08 & $x$ & $x$ & $x$ & & & & Diatom silty clay \\
\hline RH318 & 1096C-33X-2, 120-122 & 503.69 & 4.14 & & $x$ & & & & $x$ & Diatom silty clay \\
\hline $\mathrm{RH} 303$ & 1095B-5H-4, 94-96 & 126.44 & 4.18 & $x$ & $x$ & & & & & Diatom silty clay, B \\
\hline RH319 & 1096C-34X-1, 115-117 & 512.55 & 4.20 & & $x$ & $x$ & $x$ & & $x$ & Muddy diatom ooze, B \\
\hline RH394 & 1095B-7H-7, 10-12 & 149.07 & 4.63 & $x$ & $x$ & & & & & Diatom clayey silt \\
\hline $\mathrm{RH} 304$ & 1095B-9H-3, 100-102 & 163.00 & 4.95 & $x$ & $x$ & & & & $x$ & Diatom silty clay, B \\
\hline $\mathrm{RH} 305$ & 1095B-9H-6, 91-93 & 167.41 & 5.06 & & $x$ & $x$ & & & $x$ & Muddy diatom ooze \\
\hline RH395 & $1095 \mathrm{~B}-12 \mathrm{H}-1,81-83$ & 188.31 & 5.45 & $x$ & $x$ & $x$ & & $x$ & $x$ & Diatom-bearing silty clay \\
\hline RH306 & 1095B-14X-1, 19-21 & 205.19 & 5.80 & & $x$ & & $x$ & & $x$ & Diatom-bearing silty clay, B \\
\hline $\mathrm{RH} 307$ & 1095B-14X-2, 135-137 & 207.80 & 5.85 & $x$ & $x$ & $x$ & $x$ & & $x$ & Diatom-bearing silty clay \\
\hline RH396 & 1095B-17X-2, 119-121 & 236.70 & 6.25 & $x$ & $x$ & & & & & Diatom-bearing silty clay, B \\
\hline RH397 & 1095B-17X-4, 17-19 & 238.57 & 6.26 & $x$ & $x$ & $x$ & $x$ & $x$ & $x$ & Diatom-bearing silty clay \\
\hline RH398 & 1095B-23X-1, 100-102 & 292.70 & 6.94 & $x$ & $x$ & $x$ & $x$ & & & Diatom-bearing silty clay \\
\hline $\mathrm{RH} 308$ & 1095B-24X-3, 101-103 & 305.31 & 7.15 & $x$ & & & & $x$ & $x$ & Diatom silty clay \\
\hline RH399 & 1095B-26X-5, 103-105 & 327.63 & 7.59 & $x$ & $x$ & $x$ & & $x$ & $x$ & Diatom-bearing silty clay \\
\hline RH309 & 1095B-29X-1, 126-128 & 350.76 & 7.99 & $x$ & $x$ & & & & & Diatom-bearing silty clay \\
\hline $\mathrm{RH} 310$ & 1095B-29X-4, 63-65 & 354.63 & 8.05 & $x$ & $x$ & & & $x$ & $x$ & Diatom silty clay \\
\hline $\mathrm{RH} 400$ & $1095 B-34 X-4,53-54$ & 402.33 & 8.64 & $x$ & $x$ & $x$ & $x$ & $x$ & $x$ & Diatom-bearing silty clay \\
\hline RH401 & $1095 B-34 X-6,34-35$ & 405.14 & 8.65 & $x$ & $x$ & $x$ & $x$ & & $x$ & Diatom-bearing silty clay, B \\
\hline RH311 & $1095 B-39 X-5,50-52$ & 451.60 & 9.10 & & $x$ & $x$ & & $x$ & $x$ & Diatom-bearing silty clay, B \\
\hline RH312 & 1095B-42X-3, 120-121 & 478.30 & 9.28 & & $x$ & $x$ & & $x$ & $x$ & Silty clay \\
\hline RH402 & 1095B-50X-1, 91-93 & 542.61 & 9.88 & $x$ & $x$ & $x$ & $x$ & $x$ & $x$ & Silty clay \\
\hline
\end{tabular}

Notes: Samples are arranged in order of age. STOM = structured organic matter, USTOM = unstructured organic matter. B (in lithology column) = bioturbated sample; all others are laminated. 
C.J. Pudsey ANd R. HARland

Data Report: Dinoflagellate Cyst Analysis of Neogene Sediments

Table T2. Occurrence of dinoflagellate cyst taxa in each sample.

\begin{tabular}{|c|c|c|c|c|c|c|c|c|c|c|c|c|c|c|}
\hline Sample & $\begin{array}{l}\text { Depth } \\
\text { (mbsf) }\end{array}$ & $\begin{array}{l}\text { Age } \\
\text { (Ma) }\end{array}$ & 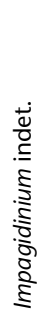 & 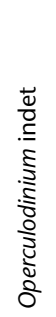 & 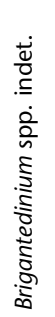 & 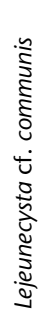 & 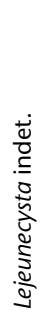 & 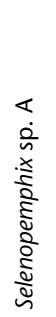 & 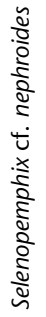 & 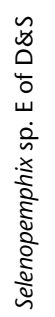 & 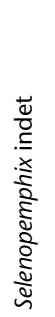 & 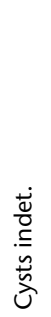 & Total & $\begin{array}{c}\text { Diatoms } \\
(\%)\end{array}$ \\
\hline RH313 & 14.70 & 0.21 & & & & & & & & & & & 0 & 28 \\
\hline RH314 & 19.20 & 0.27 & & & & & & & & & & 1 & 1 & 1 \\
\hline RH315 & 162.59 & 1.99 & & & & & & & & & & & 0 & 16 \\
\hline RH316 & 165.59 & 2.03 & & & & & & & & & & & 0 & 4 \\
\hline RH403 & 211.94 & 2.55 & & & & & 1 & & & & & & 1 & 16 \\
\hline RH317 & 302.34 & 3.01 & & & 7 & 2 & 3 & & & & 4 & 4 & 20 & 25 \\
\hline RH302 & 122.08 & 4.08 & & & & & & & & & & & 0 & 25 \\
\hline RH318 & 503.69 & 4.14 & & & 15 & & & & & & 2 & & 17 & 30 \\
\hline $\mathrm{RH} 303$ & 126.44 & 4.18 & & & & & & & & & & & 0 & 35 \\
\hline RH319 & 512.55 & 4.20 & & & 4 & & & & & & & 1 & 5 & 64 \\
\hline RH394 & 149.07 & 4.63 & & & & & & & & & & & 0 & 26 \\
\hline RH304 & 163.00 & 4.95 & & & 30 & & 1 & & & & & & 31 & 29 \\
\hline RH305 & 167.41 & 5.06 & & & 23 & & & & & & & & 23 & 51 \\
\hline RH395 & 188.31 & 5.45 & & & 1 & & & & & & & & 1 & 10 \\
\hline RH306 & 205.19 & 5.80 & 1 & & & & & & & & & & 1 & 15 \\
\hline RH307 & 207.80 & 5.85 & & & 4 & 4 & & & & & & & 8 & 16 \\
\hline RH396 & 236.70 & 6.25 & & & & & & & & & & & 0 & 34 \\
\hline RH397 & 238.57 & 6.26 & & & 42 & & & & 1 & & & & 43 & 11 \\
\hline RH398 & 292.70 & 6.94 & & & & & & & & & & & 0 & 12 \\
\hline RH308 & 305.31 & 7.15 & & 1 & 12 & & 1 & 24 & 7 & 13 & 2 & & 60 & 27 \\
\hline RH399 & 327.63 & 7.59 & & & 25 & 5 & & 4 & 2 & 8 & & & 44 & 16 \\
\hline RH309 & 350.76 & 7.99 & & & & & & & & & & & 0 & 20 \\
\hline RH310 & 354.63 & 8.05 & & 1 & 24 & 18 & & 1 & & 1 & 1 & & 46 & 27 \\
\hline RH400 & 402.33 & 8.64 & & & 2 & 4 & 5 & & & & 3 & & 14 & 20 \\
\hline RH401 & 405.14 & 8.65 & & & 1 & & & & & & & & 1 & 21 \\
\hline RH311 & 451.60 & 9.10 & & & 18 & 8 & & & 1 & 2 & & 1 & 30 & 24 \\
\hline RH312 & 478.30 & 9.28 & & & 10 & 1 & 2 & & & & & & 13 & 8 \\
\hline RH402 & 542.61 & 9.88 & & & 12 & 18 & & & & 6 & & & 36 & 0 \\
\hline
\end{tabular}

Note: Samples are arranged in order of age. D\&S = Duffield and Stein (1986). 